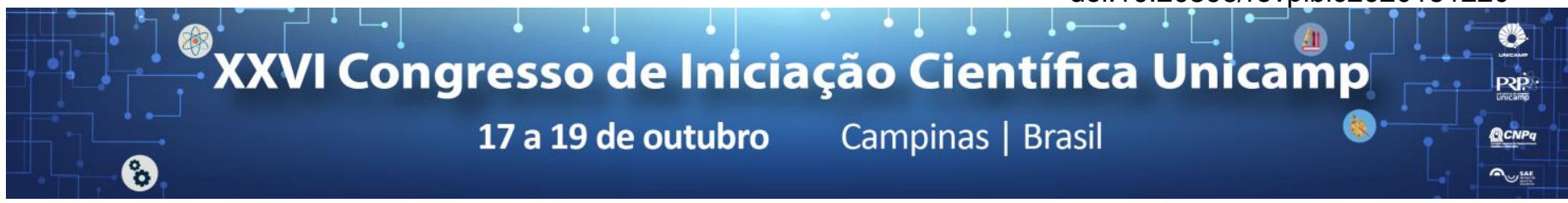

\title{
Biobanco de Placenta em Centro Terciário de Atenção à Saúde da Mulher: necessidade em tempos de Arboviroses e fundamental para avanços científicos e pesquisa translacional.
}

\section{Rodolfo R. Japecanga*, José Paulo S. Guida, Maria Laura Costa.}

\section{Resumo}

O armazenamento de tecido placentário, com coleta sistemática, poderá ampliar a possibilidade de pesquisa translacional na área. Uma complicação que tem chamado a atenção mundialmente é a epidemia por zika vírus (ZIKV) e associação com microcefalia e malformações fetais. Ainda não se sabe os mecanismos de transmissão transplacentária e a coleta destas placentas é uma necessidade, para colaborar com a investigação clínica e diagnóstico de casos suspeitos e também, para possibilitar estudos visando a compreensão da fisiopatologia da doença. Outra prioridade em obstetrícia, com papel central da placenta e etiologia ainda pouco esclarecida é a Préeclâmpsia, doença que acomete até $10 \%$ de todas as gestações, sendo uma das principais causas de morbidade e mortalidade materna no Brasil. Para possibilitar a investigação da fisiopatologia destas condições e futuramente de demais doenças, a criação de um biobanco de placenta no CAISM representa um passo importante.

\section{Palavras-chave:}

Placenta, Biobanco, Zikv, Pré-eclâmpsia.

\section{Introdução}

Biobancos são coleções organizadas de material biológico humano e informações associadas, armazenados para fins de pesquisa, conforme regulamento ou normas técnicas, éticas e operacionais pré-definidas, sob-responsabilidade e gerenciamento institucional, sem fins comerciais. ${ }^{1}$

A placenta representa a interface entre a mãe e o feto. Anormalidades neste circuito estão associadas ao desenvolvimento de doenças e podem ajudar a entender a fisiopatologia de condições ainda pouco estudadas (como ZIKV) ou de fisiopatologia incerta (como pré-eclâmpsia).2,3 Objetivo: implantar protocolo de coleta sistemática de placentas em maternidade de alto risco, priorizando casos de ZIKV e pré-eclâmpsia

\section{Resultados e Discussão}

Entre maio/16 a junho/18, foram coletadas amostras de 142 placentas.

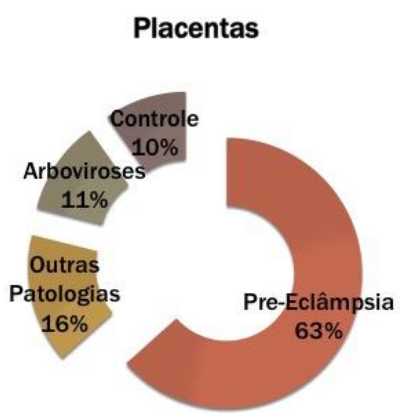

A idade gestacional dos casos coletados variou entre 24 a 41 semanas. Todas as amostras foram armazenadas no Biobanco, com sucesso, após assinatura de TCLE e autorização da gestante. Os resultados maternos e perinatais foram também coletados a partir do prontuário médico e armazenados em banco de dados específico. A coleta sistemática envolve material da membrana amniótica(MA), do tecido viloso(VC), da membrana basal(MB), do cordão umbilical(CORDÃO) e da placa coriônica(PC), prevendo assim, maior representatividade placentária, com escolha de 4 regiões equidistantes do cordão umbilical. O material é coletado para fixação do tecido em parafina (Fig 2) e congelação a $-80^{\circ} \mathrm{C}$, para futura extração de proteína e RNA/DNA (Fig 1). Além disso, cada placenta tem sua face materna e fetal fotografada, para avaliação da inserção do cordão, peso e volume documentados.

Figura 1. Coleta de Amostras em criotubo

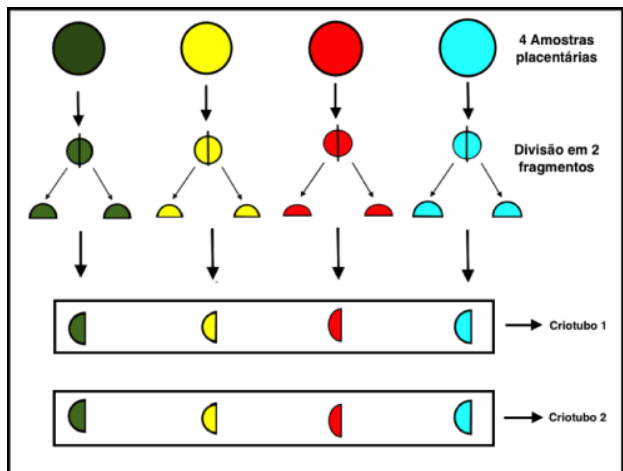

Figura 2. Tecido para fixação em parafina.

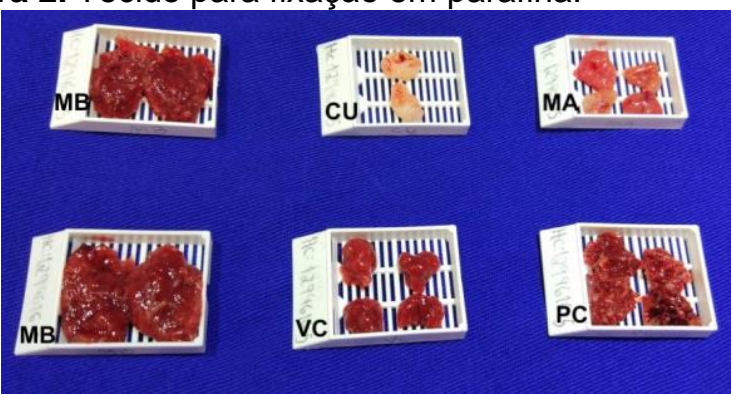

\section{Conclusões}

A coleta sistemática de placentas foi factível em maternidade de alto risco. Com financiamento apropriado e ampliação da estrutura já montada pretendemos coletar material rotineiramente de todos os partos, além de coletar outros materiais biológicos, como sangue materno e de cordão, leite materno, urina. Desta forma, será possível avançar muito no desenvolvimento de pesquisa translacional em Obstetrícia.

$\overline{{ }^{1} \text { Resolução CNS número 441, } 441}$ (2011). ${ }^{2}$ Zika Virus on the Move. Cell 2016, 164(4):585-587. ${ }^{3}$ Ben W J Mol, et al. Pre Eclampsia. Lancet 2016; 387: 999 1011 